Business Finance and the Capital Market 
Other books by the authors

Case Studies in Business Finance and Financial Analysis

K. Midgley \& R. G. Burns

Accounting Case Studies

K. Midgley \& R. G. Burns

from the Business Case Studies Series edited by R. G. Burns and K. Midgley

Also

Book-keeping \& Accounts

by K. Midgley \& H. J. Goater

Economics Almanac

edited by R. L. Carter and K. Midgley 


\section{Business Finance and the Capital Market}

Kenneth Midgley B.A., B.Sc. (Econ.), A.C.I.S.

Ronald G. Burns M.Phil., A.C.C.A.

Macmillan Education 
๑ Kenneth Midgley and Ronald G. Burns 1969, 1972

First edition 1969

Reprinted 1971

Second edition 1972

Published by

THE MACMILLAN PRESS LTD

London and Basingstoke

Associated companies in New York Toronto

Dublin Melbourne Johannesburg and Madras

SBN 333146573

ISBN 978-0-333-14657-6 ISBN 978-1-349-01829-1 (eBook) DOI 10.1007/978-1-349-01829-1

Text set in 9/11 pt. IBM Baskerville, printed by photolithography, and bound in Great Britain at The Pitman Press, Bath. 


\section{Contents}

Preface to the Second Edition vii

Preface to the First Edition viii

PART ONE: INTRODUCTION 3

1 The Capital Market

PART TWO: BUSINESS CAPITALISATION 13

2 Finance of a New Business

Risks - Calculation of Initial Capital Requirements - The Problem of Financing

3 Forming a Limited Company

Reasons for Forming a Limited Company - Methods of Incorporation - Converting a Private Company into a Public Company Underwriting - Methods of Issue - The Volume of New Issues Issuing Houses - Types of Long-Term Company Finance

4 Capital Structures

General considerations of the Type of capital to Raise - Use of Short-Term Finance - Choosing the Capital Structure - Pricing the Capital Issued - Gearing or Leverage - Control Through Capital Structure - The Effect of Taxation on Capital Structures - Some Examples of Capital Structure

5 Other Methods of Raising Finance, Including the Use of Special Institutions

Short-Term Finance - Medium-Term Finance - Long-Term Finance

- Special Financial Institutions - Borrowing Internationally -

Government Finance for Industry - Bank Aid to Business

6 Financing Export Trade

Insuring the Risks. Comprehensive Policies - Specific Policies

Export Finance. Short-Term Finance - Medium-Term Finance - Long-

Term Finance - Bank of England Refinancing Scheme

PART THREE: FINANCIAL CONTROL

7 The Management of Funds, Planning and Budgeting

The circular Flow of Funds - Profit-Planning and the Finance

Budget - Sources and Uses of Funds Statements

8 Some Accounting Problems

Depreciation - Problems of Pricing - Measurement of Profit in Re-

lation to Business Capital 
9 Evaluating the Return on Capital Expenditure

Some Basic Principles - Alternative Methods of Evaluation - Discounting Techniques; Methods of Application - Discounting Techniques; The Principles Involved

10 The Allocation of Profits

Dividends. Profits which are Legally Distributable - Shareholders' Dividend Rights - Factors Affecting the Size of Dividends Paid - Dividend Policies in Practice

Employee Participation in Profits. Pension Schemes - Employee Profit Sharing

Reserves. Creating Reserves - Specific Reserves - General Reserves Bonus Issues

\section{PART FOUR: BUSINESS EXPANSION}

11 Reasons for Expansion

Empire Building - The Economies of Large-Scale Enterprise - The

Case for Expansion - The Expansion of the Giants - Expansion and Government Policy

12 Business Combinations

I Financial Statement Analysis and Valuations

Analysis and Interpretation of Accounts - Business Valuations -

Terms to be Offered

II Procedural Aspects and Recent Developments

Legal Matters - Contested Take-Over Bids - The Industrial Reorganisation Corporation - Monopolies and Mergers Act 1965 Recent Business Combinations

\section{PART FIVE: IMPACT OF TAXATION}

13 Business Taxation

Income Tax - Profits Tax - Corporation Tax - Death Duties -

Capital Gains Tax - Selective Employment Tax - Accounting

Treatment of Taxation - Some effects of recent major changes in taxation of Company Profits - The Value Added Tax

\section{PART SIX: SAVINGS}

14 Channelling Savings

Personal Savings - Financial Institutions - National Flow of Funds

15 Market Behaviour and the Stock Exchange

Economic Factors - Government Controls - Market Forecasting Stock Markets

16 Savers and their Portfolios

Some Fundamental Considerations - Tax Considerations - Securities for Savers

PART SEVEN: CONCLUSION 


\section{Preface to the Second Edition}

There have been a number of developments in the area of business finance during the three years since we completed our drafts for the first edition of this book. The British tax system, never a particularly stable element of the economy in post-war years, has been subjected to several far-reaching reforms some of which will not be fully implemented until 1973. Other important recent events include further large industrial amalgamations, changes in methods of bank credit control, the decision to enter the Common Market, and a generally more rigorous approach to the control of the industrial climate, as evidenced by the government's refusal to bail out Rolls Royce Ltd, the Industrial Relations Act, and increased resistance to high wage claims.

Such events, and the need to bring statistics up to date wherever possible, have made it imperative that a substantial revision should be undertaken so as to maintain our original aim of presenting business finance as a dynamic economic activity in which we are all participators in one role or another.

Since the first edition was published we have written a complementary volume entitled 'Case Studies in Business Finance and Financial Analysis'. This book enables readers to apply many of the principles mentioned in our textbook to actual or closely simulated business situations, and though the two volumes can be used separately, together they form a set providing the theoretical and applied groundwork for a year's course.

K. M.

R. G. B. 


\section{Preface to the First Edition}

The scope and rationale of this book is discussed at some length in the introductory chapter. Business finance is no longer, if it ever was, an esoteric study, of interest only to a narrow sector of the public. We are all financiers in a small way. We borrow from building societies, banks and hire-purchase companies, and invest in houses, furniture and cars. We provide funds for business and Government through a variety of channels. Financial matters more frequently than ever encroach on to the front pages of our newspapers: mergers, tax measures, Bank rate changes, business failures, international loans - such news items readily capture the headlines nowadays. In spite of a growing public interest there are comparatively few books on business finance which cover the subject as a whole, and we hope that this book will assist practising businessmen to view the subject of finance in a wider perspective than that to which they may be accustomed, as well as provide a useful aid to students in their preparation for examinations.

The syllabuses which are substantially covered by the contents of this book are those in business finance for the final examinations of professional bodies, Higher National Diplomas and Certificates in Business Studies, degree level examinations, and Diplomas and Certificates in Management Studies. To assist the student in tracking down particular topics, there are included, in addition to the usual index, a detailed list of contents at the front of the book, and brief introductory summaries to chapters.

We give some indication of the help we have received from other writers in the footnotes and reading lists, and we thank the publishers and authors of works which have been quoted. Our thanks are also extended to colleagues who have read and criticised certain chapters, and not least to our wives, whose privations during the long silent hours of preparation evoked some penetrating criticisms well beyond the subject of finance.

K. M.

R. G. B. 